\title{
Light microscopic and ultrastructural study of sporulation of Goussia gadi (Apicomplexa: Coccidia) in the swimbladder wall of haddock Melanogrammus aeglefinus
}

\author{
C. M. Morrison ${ }^{1}$, J. P. Leger ${ }^{2}$, C. A. Morrison ${ }^{1}$ \\ ${ }^{1}$ Department of Fisheries and Oceans, Biological Sciences Branch, Halifax, Nova Scotia, Canada B3J 2S7 \\ ${ }^{2}$ Anatomy Dept, Dalhousie University, Halifax, Nova Scotia, Canada B4H 4 H7
}

\begin{abstract}
During sporulation of Goussia gadi (Fiebiger, 1913), the zygote divides into 4 sporoblasts, in each of which 2 sporozoites are formed. The membranes enclosing the wall-forming bodies and a membrane formed around each sporoblast function as an oocyst wall. The meaning of the term 'oocyst wall' for coccidia in fish hosts is discussed. The wall-forming bodies decrease in size as the thick sporocyst wall is formed. The sporocyst is ellipsoid, and its wall consists of longitudinal plates. Sporozoites are released to re-infect the swimbladder wall.
\end{abstract}

KEY WORDS: Coccidia - Goussia gadl Melanogrammus aeglefinus - Oocyst wall Sporulation . Ultrastructure

\section{INTRODUCTION}

The merogony and gametogony of Goussia gadi have been described using drawings of these stages as seen using light microscopy (Fiebiger 1913); they have been further studied using light and transmission electron microscopy (Morrison et al. 1993a, b). Fiebiger (1913) also described sporogony using drawings, and the mature sporocyst has been studied using transmission and scanning electron microscopy (Odense \& Logan 1976). In this account the development of the sporocyst and the sporozoites of $G$. gadi infecting haddock Melanogrammus aeglefinus are described using light, transmission and scanning electron microscopy.

\section{MATERIALS AND METHODS}

Samples were obtained and processed for light and transmission electron microscopy as described in Morrison et al. (1993a). For scanning electron microscopy (SEM), samples of the yellow matter from the lumen of a swimbladder which had been slit ventrally and then fixed whole for light and electron microscopy were removed, dehydrated in acetone, critical point dried and sputter-coated. Some of the fixing fluid from these samples containing small fragments of yellow material was filtered using a buchner funnel with filter paper and suction, and the filter paper was then cut into pieces and prepared for SEM as above.

\section{RESULTS}

Zygotes divide into 4 sporoblasts, surrounded by an electron-dense layer containing wall-forming bodies, and a layer consisting of fine filaments (Fig. 1). After division, some sporoblasts are connected by thin strands of cytoplasm (Fig. 2), but in more advanced specimens the sporoblasts are separate with a central residuum (Fig. 3). The sporoblasts may not all be at the same stage of development. Each sporoblast is limited by a membrane, surrounded by a second membrane then an electron-dense layer containing wall-forming 
bodies (Fig. 4). If present, the host cell is reduced to a thin layer of cytoplasm, or just a membrane surrounding a large parasitophorous vacuole. At a more advanced stage of development the nucleus is found at one end of the sporoblast, surrounded by a double membrane, electron-dense material and more membranes (Fig 5).

In more mature sporoblasts, a cleft separating the nuclear region from the cytoplasm containing the lipid droplets and amylopectin granules is evident, and the cytoplasm containing the nucleus is more elongate. A sporocyst wall has begun to form outside the double cell membrane, being thicker at the nuclear end, and the wall-forming bodies are small and irregularly shaped (Fig. 6). In cross section, the curved sporoblast appears to consist of 2 separate par is (Fig. 7$)$. The sporocyst wall is thickened all around the sporoblast after the nucleus has divided in two (Fig. 8). Two sporozoites are formed from each sporoblast, leaving a small sporocyst residuum (Fig. 9). When properly fixed the more mature sporocysts are elliptical, the thick wall has 2 sutures, and the sporozoites are elongate and coiled around each other (Fig. 10). Sporocysts which were less well fixed had a crenulated outline and electrondense contents. The apical complex of each sporozoite is evident, and there is a crystalloid area and a region containing many mitochondria near the anterior end, and several lipid and amylopectin granules more posteriorly. There are numerous small dark vesicles in the peripheral cytoplasm.

The sporocysts are $15.8(13.8$ to 17.9$) \times 10.9$ (8.3 to 1.3.8) $\mu \mathrm{m}$ (from 50 measurements of sporocysts in a squash preparation of fixed material). Each sporocyst is surrounded by the remnants of a membrane which formed around each sporoblast. Each group of sporocysts is surrounded by a membrane-bound electrondense layer containing the remains of the wall-forming bodies which surrounded the macrogamont, which performs the function of an oocyst wall.

The suture in the mature sporocyst consists of a central double membrane surrounded by a light region (Fig. 11) There are transverse repeating units as well. as longitudinal striations in the spore wall (Fig. 12), which can be up to about $480 \mathrm{~nm}$ in width. At the outer border of the spore wall is a dark zone bordered by light zones, and outside this is a double membrane, then a layer of small filaments. When the sporozoites are released the spore wall opens at the suture to form 2 valves, and tho central membrane of the suture is left to one side (Figs. $13 \& 14$ ). The sporocysts have longitudinal ridges (Figs. $15 \& 16$ ). They tend to open first along one side (Fig. 15). In sectioned material the organisation of the spore wall is disrupted where there is a ridge, so that in cross section the wall appears to be formed of a series of plates (Figs. 13 \& 14)

Sporozoites are found within the oocyst membrane (Fig. 14) or free among other parasites and host cell remains (Fig, 17). The sporozoites are 2 to $4 \mu \mathrm{m}$ wide and up to $16 \mu \mathrm{m}$ long in sectioned material (the whole length is not included in a section). The pellicle is trilayered, with an outer membrane which is a continuous plasmalemma, and 2 inner membranes which are closely apposed, and interrupted at the polar rings. Two preconoidal rings are present, and microtubules are present beneath the peilicie. The secretory ducts of rhoptries extend into the conoid, and the convoluted micronemes appear as electron-dense structures (Fig. 18). In some specimens the spirally arranged fibres forming the conoid can be seen (Fig. 19), and there is a micropore (Fig. 20), which may have a feeding vesicle associated with it (Fig. 17). Crystalloid bodies composed of hexagonal arrays are often present (Fig. 21). Posterior to the nucleus is a concentric whorl of smooth membraned cisternae, presumably a Golgi apparatus (Figs. $17 \& 22$ )

\section{DISCUSSION}

The development of sporoblasts, sporocysts and sporozoites in Goussia gadi is similar to that described for Goussia spraguei (Morrison \& Poynton 1989). The dimensions of $G$ gadi sporocysts are slightly larger than those obtained by Fiebiger (1913) and Odense \& Logan (1976). Fiebiger also observed that the development of the sporoblasts from any one zygote was not necessarily synchronous. The open sporocysts were described by Fiebiger (1913) as being united by a longitudinal suture in the manner of a pod, and the valves only seem to completely separate after release of the sporozoites. Since the samples were obtained on board ship, it was not possible to freeze specimens to achieve good preservation of sporozoites (Chobotar \& Scholtyseck 1982) but, as was found with Goussia clupearum (Morrison \& Hawkins 1984), fixative was apparently able to penetrate some sporocysts through the sutures, so some well-preserved sporozoites were obtained.

The segments or plates comprising the sporocyst

Abbreviations used in figures. $\mathrm{AG}=$ amylopectin granule, $\mathrm{C}=$ conoid, $\mathrm{Cl}=\mathrm{cleft}, \mathrm{Cr}=$ crystalloid body, $\mathrm{CR}=\mathrm{preconoidal}$ rings, DV $=$ dense vesicles, $F F=$ fine filamentous layer, $G B=$ Golgi body, $\mathrm{HC}=$ host cytoplasm, $\mathrm{LD}=$ lipid droplet, Mem $=$ membrane, $\mathrm{Mi} \equiv$ mitochondrion, $\mathrm{Mic}=$ microtubule, $\mathrm{Mn}=$ microneme, $\mathrm{Mp}=$ micropore, $\mathrm{Nu}=$ nucleus, $\mathrm{OM}=0 \mathrm{ocyst}$ membrane, $\mathrm{OR}=0 \mathrm{ocyst}$ residuum, $\mathrm{Pl}=$ plate, $\mathrm{PR}=$ polar rings, $\mathrm{R}=$ ridge, $\mathrm{Rh}=$ rhoptry, $\mathrm{S}=$ suture $\mathrm{SM}=$ sporoblast or sporocyst membrane, $\mathrm{SR}=\mathrm{sporo}$ cyst residuum, $\mathrm{SW}=$ sporocyst wall, $\mathrm{V}=$ vesicle, $\mathrm{WB}=$ wall - forming body 


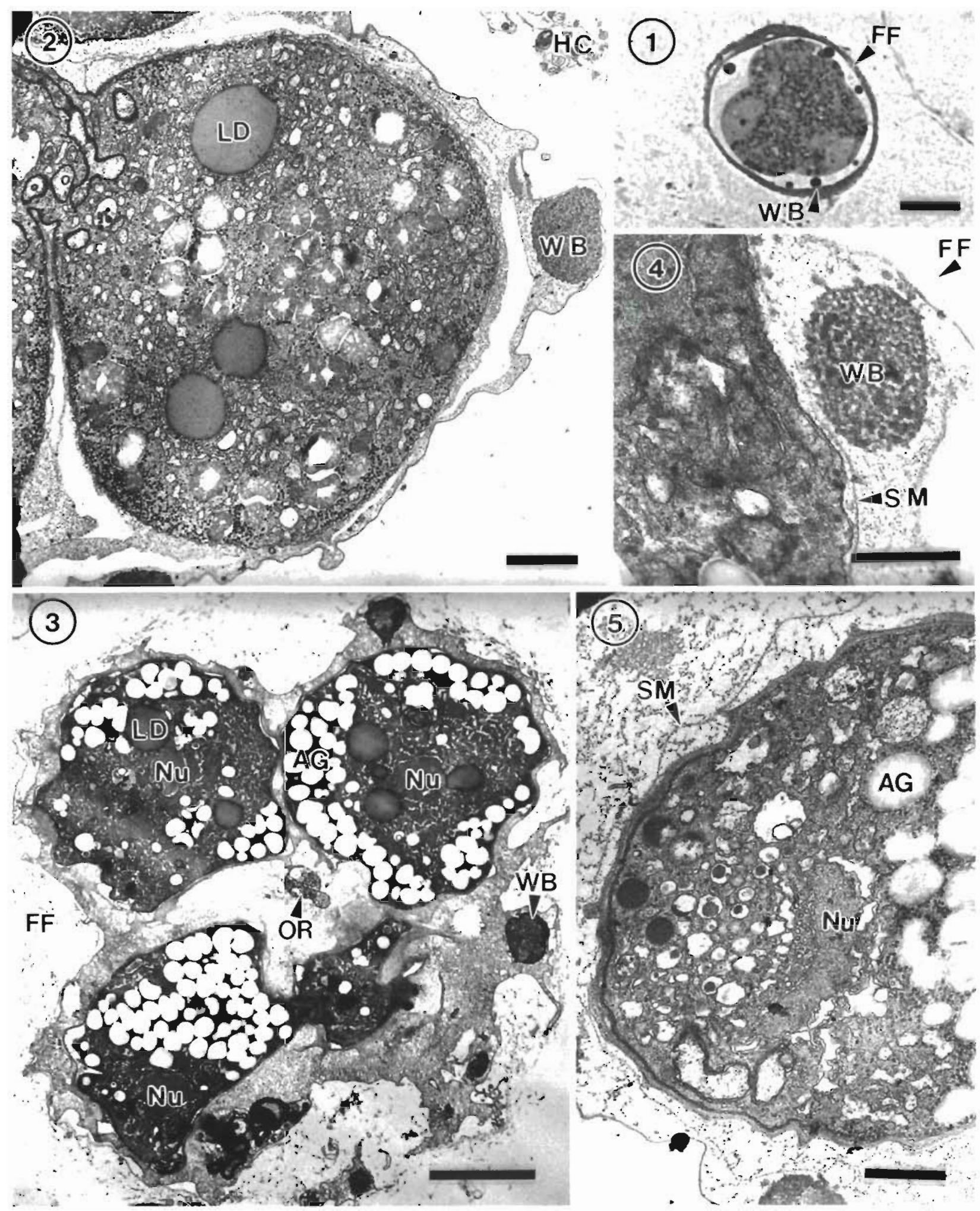

Figs. 1 to 5. Goussia gadi parasitizing Melanogrammus aeglefinus. Fig. 1. Developing sporoblasts with wall-forming bodies, surrounded by a layer of fine filaments. $0.5 \mu \mathrm{m}$ section of EM sample stained with toluidine blue; scale bar $=10 \mu \mathrm{m}$. Fig. 2 . Rosette of sporoblasts attached by strands of cytoplasm, surrounded by an electron-dense layer containing wall-forming bodies. TEM; scale bar $=2 \mu \mathrm{m}$. Fig. 3 . Rosette of sporoblasts with small central oocyst residuum. TEM; scale bar $=5 \mu \mathrm{m}$. Fig. 4 . Membrane surrounding limiting membrane of the sporoblast. TEM; scale bar $=0.5 \mu \mathrm{m}$. Fig. 5 . Nuclear end of sporoblast enclosed by several 

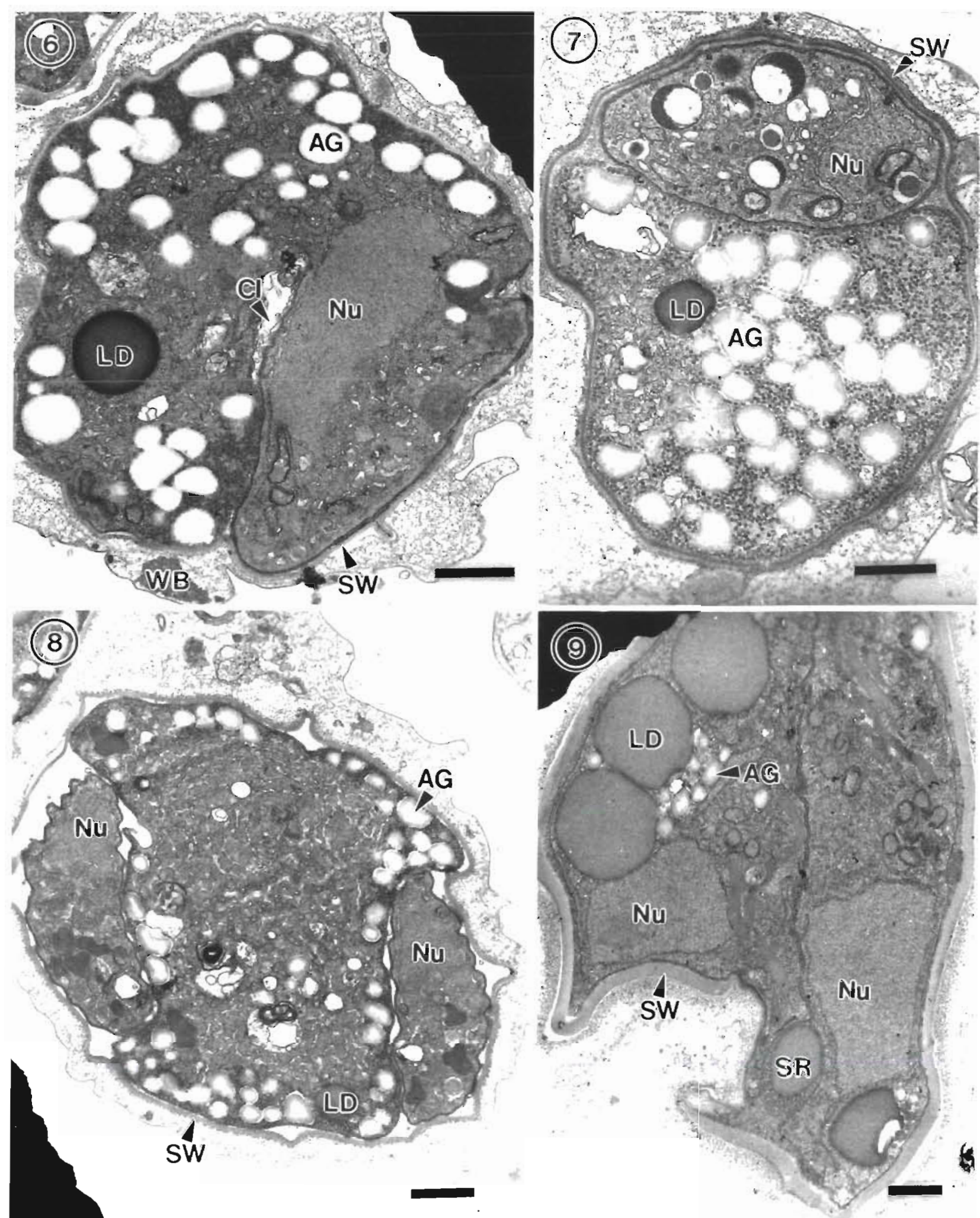

Figs. 6 to 9. Goussia gadi parasitizing Melanogrammus aeglefinus. Fig. 6. Curved sporoblast with a thin spore wall at the nuclear end, and lipid droplets and amylopectin granules in the remaining cytoplasm. A small wall-forming body is present. TEM; scale bar $=1 \mu \mathrm{m}$. Fig. 7. Cross section of a curved sporoblast. TEM; scale bar $=1 \mu \mathrm{m}$. Fig. 8 . Sporocyst following nuclear division and development of the sporocyst wall. TEM; scale bar $=1 \mu \mathrm{m}$. Fig. 9 . Sporocyst containing 2 sporozoites and a sporocyst residuum. 


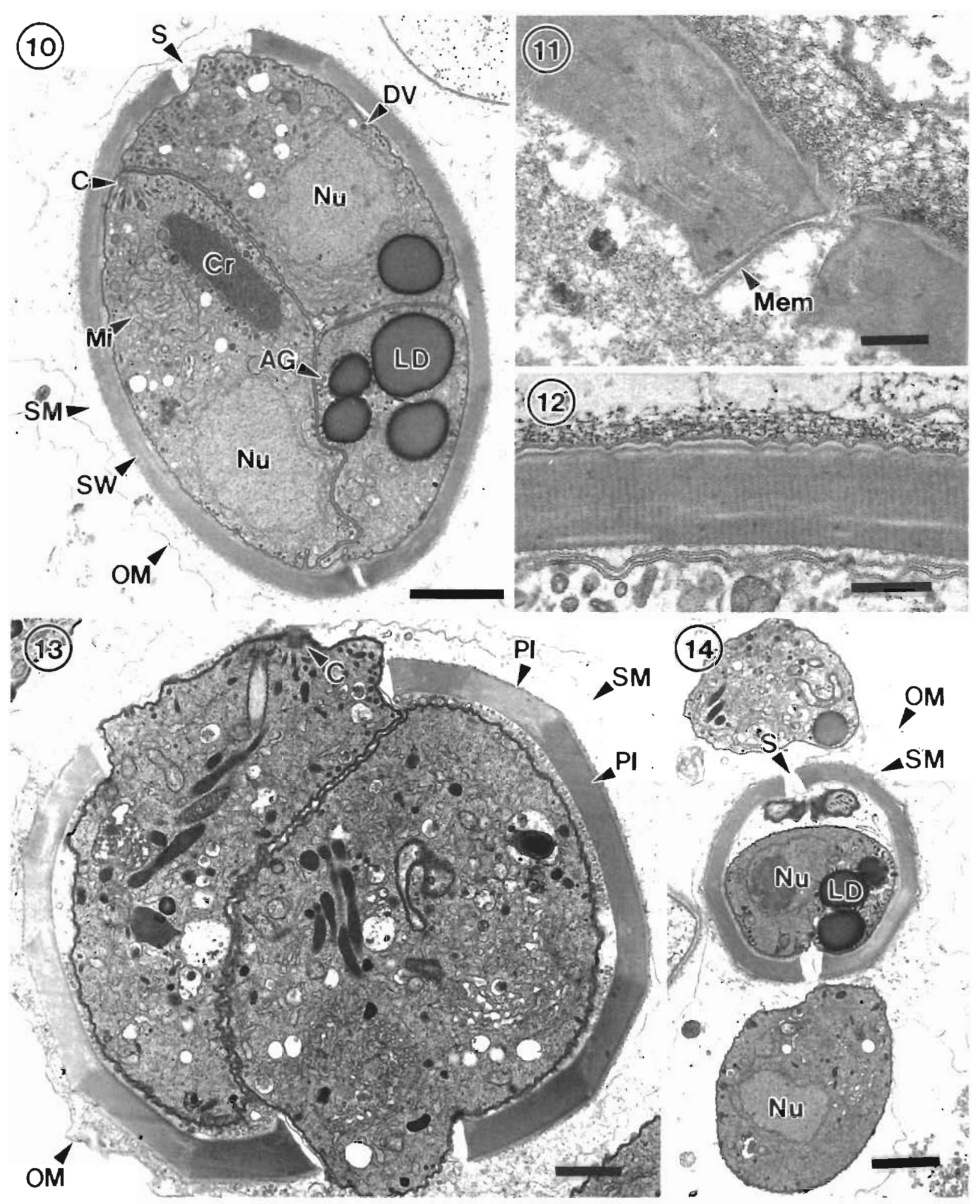

Figs. 10 to 14. Goussia gadi parasitizing Melanogrammus aeglefinus Fig 10 Sporocyst containing elongate sporozoltes, with sutures in the wall. TEM; scale bar $=2 \mu \mathrm{m}$. Fig. 11. Double membrane in the centre of the suture in the sporocyst wall TEM, scale bar $=0.25 \mu \mathrm{m}$. Fig. 12. Cross striations and longltudınal fissures in the sporocyst wall. Outside the wall 15 a dark zone bordered by light zones, a double membrane, then a filamentous layer TEM. scale bar $=025 \mu \mathrm{m}$. Fig. 13. Sporozoltes leaving sporocyst The sutures are open, with the central membrane pushed to one side The sporocyst wall is formed of a series of plates TEM, scale bar $=1 \mu \mathrm{m}$. Fig. 14. Sporocyst and released sporozortes surrounded by an oocyst membrane TEM, scale bar $=2 \mu \mathrm{m}$ 

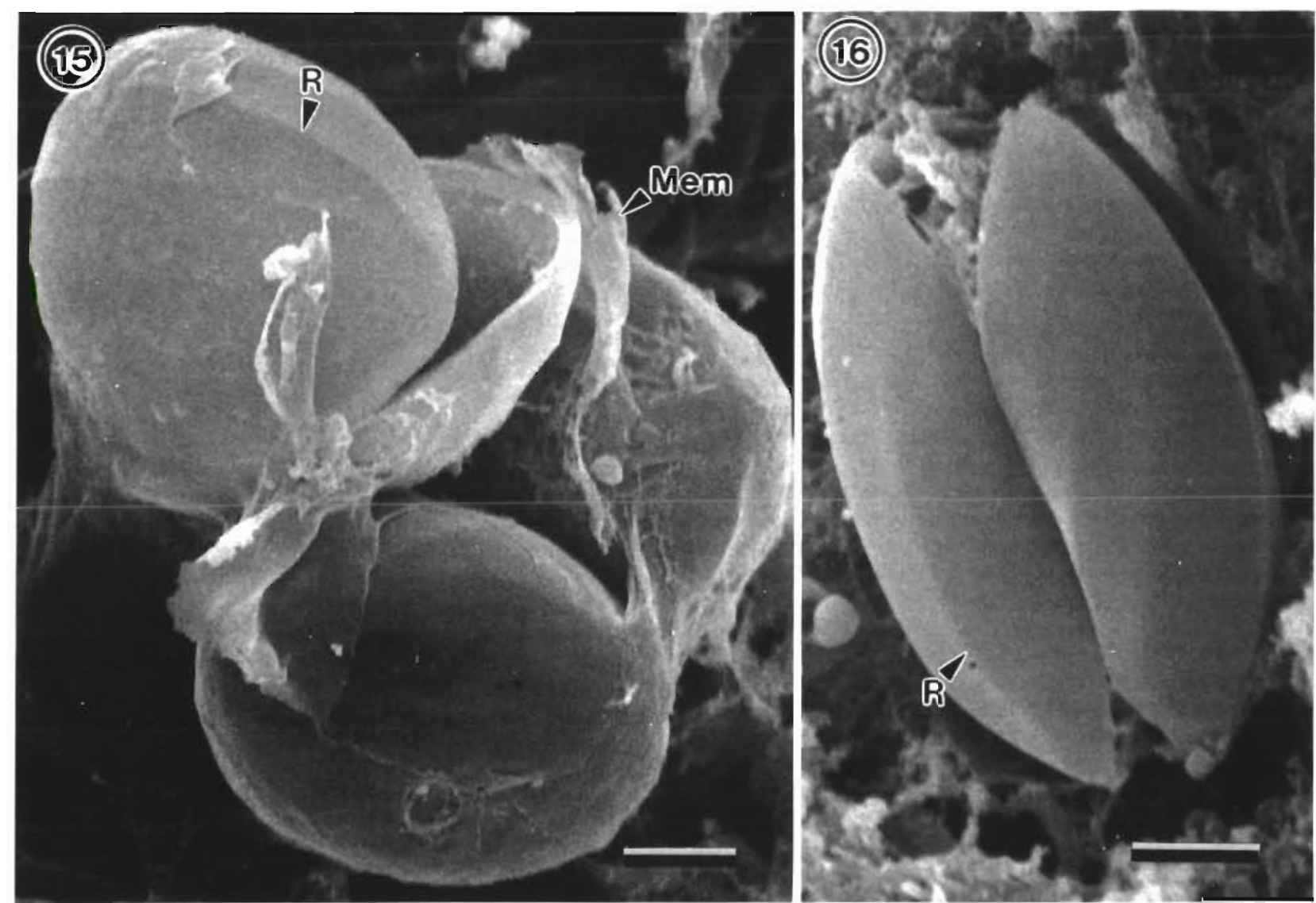

Figs. 15 \& 16. Goussia gadi parasitizing Melanogrammus aeglefinus. Fig. 15. Group of sporocysts partially covered by sporocyst and oocyst membranes, one with valves partially separated. SEM; scale bar $=2.5 \mu \mathrm{m}$. Fig. 16 . Sporocyst with valves separated. $\mathrm{SEM}_{\text {; }}$ scale bar $=2.5 \mu \mathrm{m}$

wall seem to be an unusual feature of Goussia gadi They were reported as occurring only in immature sporocysts by Odense \& Logan (1976), but in the present study they were also found in mature sporocysts using transmission and scanning electron microscopy. The longitudinal ridges shown in scanning electron micrographs by Odense \& Logan (1976) are more prominent than those found in the present account, probably because air drying occurred during specimen preparation. Plates have been described in coccidia from terrestrial vertebrates (Ferguson et al. 1979), but the junctional regions open to release the spores, and so these plates are equivalent to the 2 valves of Goussia spp. Plates described by Paperna \& Landsberg (1985) consist of 3 or more layers in the subpellicular cytoplasm which fuse to form the sporocyst wall; they are not plates which abut laterally as in G. gadi. $G$. gadi was placed in the subgenus Plagula by Overstreet et al. (1984) because sutures and a veil are present, as in Calyptospora funduli. However, this veil, the membrane surrounding each sporocyst, is not always as complete as that surrounding $C$. funduli. No support- ing structures, such as the sporopodia of $C$. funduli, were present.

Fiebiger (1913) describes highly refractile lipid droplets in the sporoblasts of Goussia gadi, and anterior and posterior to the nucleus of the sporozoites. Histochemical tests on refractile bodies in the sporozoites of other coccidia indicate that protein or lipoprotein is present (Ryley 1973, Ferguson et al. 1978a). Crystalloid bodies have also been reported to consist of lipoprotein (Ferguson et al, 1978a), and it has been suggested that crystalloid and refractile bodies, like amylopectin granules, store nutrients (Chobotar \& Scholtyseck 1982). Usually, only refractile bodies or crystalloids are present in sporozoites (Chobotar \& Scholtyseck 1982), although both are found in the sporozoites of G. gadi, G. spraguei (Morrison \& Poynton 1989) and Eimeria sardinae (Morrison 1991).

The concept of an oocyst wall in fish is a confusing one. The oocyst of coccidia in terrestrial vertebrates is usually a thick cyst produced by the parasite, which protects the sporulating stages when they are released from the host. The oocyst wall in piscine coccidia is 


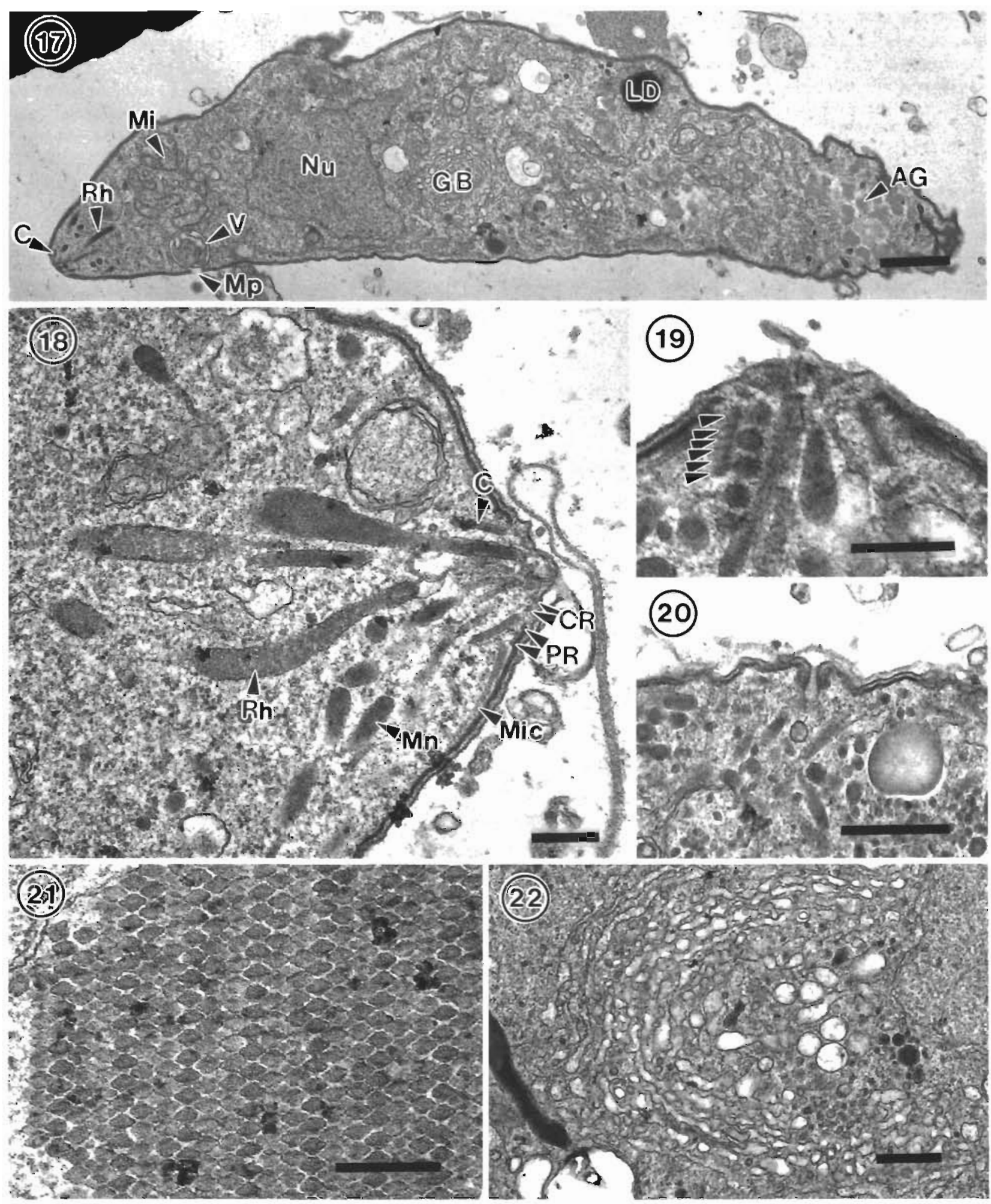

Figs. 17 to 22. Goussia gadi parasitizing Melanogrammus aeglefinus Fig 17. Free sporozoite with characternstic organelles TEM, scale bar $=1 \mu \mathrm{m}$. Fig. 18. Apical complex of sporozoite including pola a âd preconoidal nngs, rhoptries and micronemes TEM, scale bar $=0.25 \mu \mathrm{m}$. Fig. 19 . Conoid with 6 spiral turns indicated by arrows TEM, scale bar $=0.25 \mu \mathrm{m}$. Fig. 20 . Micropore of sporozoite. TEM; scale bar $=0.5 \mu \mathrm{m}$. Fig. 21 Crystallold body of sporozorte, composed of an array of hexagonally arranged crystals TEM; scale bar $=0.25 \mu \mathrm{m}$. Fig. 22. Golgr body of sporozoite, consisting of a whorl of smooth cisternae and vesicles. TEM, scale 
usually thin, and some authors use the term only for membranes of parasite origin, as in terrestrial vertebrates. whereas others use it for any thin membrane surrounding the sporulating coccidia.

For example, many piscine coccidia develop in a vacuole separated from the host cytoplasm by a single or double membrane which may be of host and/or parasite origin, although it is usually regarded as being of host origin (Chobotar \& Scholtyseck 1982). Goussia spraguei develops in such a vacuole at the apex of the epithelial cell lining the kidney tubule, and when the zygote is released into the lumen of the kidney it is surrounded by 2 membranes, the inner membrane lining the vacuole, and an outer membrane derived from the apical region of the host cell plasmalemma (Morrison \& Poynton 1989). These membranes protect the sporogonic stages, like an oocyst wall. However, membranes are also formed by the zygote, and these are termed the oocyst wall in Goussia pannonica (Lukes 1992), which develops in a similar fashion to G. spraguei, except that the 2 membranes are lost soon after release of the zygote from the intestinal wall of the host.

The sporulating stages of Goussia clupearum, Eimeria sardinae (Morrison \& Hawkins 1984) and Eimeria funduli (Hawkins et al. 1983) remain in a vacuole in the host cytoplasm. The oocyst wall of these coccidians was considered to consist of 2 membranes lining the parasitophorous vacuole, but the sporulating stages are also surrounded by membranes produced by the parasite, which could also be considered the oocyst wall. Lom et al. (1991) regarded only membranes of parasite origin as the oocyst wall of Goussi carpelli, which also sporulates in a vacuole in the host cell. The wall lining the parasitophorous vacuole containing $G$. gadi consists of only 1 membrane, as in Eimeria variabilis (Davies 1978). This often disintegrates, leaving the parasite enclosed by a thin oocyst wall formed only by membranes of parasite origin. Additional protection seems to be provided by the layer of fine filaments, the origin of which is unknown.

The wall-forming bodies found in the macrogamete of Goussia gadi appear to contribute to the sporocyst wall, since they are smaller in specimens in which the wall is forming. Dense bodies are apparently involved in wall formation in Goussia cichlidarum (Paperna \& Landsberg 1985), but not in other piscine coccidia (Paterson \& Desser 1981, Stcinhagen et al. 1990, Lom et al. 1991, Steinhagen 1991). The development of special wall-forming bodies in $G$. gadi may be related to the presence of a sporocyst wall which is similar in. morphology to those of other piscine coccidia, but is thicker than most. Osmiophilic bodies in coccidia from terrestrial animals contribute to the sporocyst wall in some species but not others (Ferguson et al. 1978 b).
Acknowledgements. We thank Dr G. McClelland for his careful review of the manuscript and helpful comments, and Ms Anne Moore for proofreading the manuscript.

\section{LITERATURE CITED}

Chobotar, B., Scholtyseck, E. (1982). Ultrastructure. In: Long, P. L. (ed.) The biology of the Coccidia. Edward Arnold, London, p. 101-156

Davies, A. J. (1978), Coccidian parasites of intertidal fishes from Wales: systematics, development, and cylochemistry J. Protozool. 25: 15-21

Ferguson, D. J. P., Birch-Andersen, A., Chr. Siim, J., Hutchison, W. M. (1979). Ultrastructural studies on the sporulation of oocysts of Toxoplasma gondii. Acta pathol. microbiol. Scand. Sect. B 87: 183-190

Ferguson, D. J. P., Birch-Andersen, A., Hutchison, W. M., Chr Sim, I (1978a). Light and glectron microscopy on the sporulation of the oocysts of Eimeria brunetti. I. Development of the zygote and formation of the sporoblasts. Acta pathol. microbiol. Scand. Sect. B 86: 1-11

Ferguson, D. J. P., Birch-Andersen, A., Hutchison, W. M. Chr Siim, J. (1978b). Light and electron microscopy on the sporulation of the oocysts of Eimeria brunetti. II. Development into the sporocyst and formation of the sporozoite. Acta pathol microbiol. Scand. Sect. B 86: $13-24$

Fiebiger, J. (1913). Studien über die Schwimmblasencoccidien der Gadusarten (Eimeria gadi n. sp.). Arch Protistenkd. 31: 95-137

Hawkins, W. E., Fournie, J. W., Overstreet, R. M. (1983). Organization of sporulated oocysts of Eimeria funduli in the gulf killifish. Fundulus grandis. J. Parasitol. 69 $496 \cdot 503$

Lom, J., Steinhagen, D., Körting, W., Dyková, I. (1991). Oocyst formation in the coccidian parasite Goussia carpelli. Dis. aquat. Org. 10: 203-209

Lukes, J (1992). Life cycle of Goussia pannonica (Molnar, 1989) (Apicomplexa, Eimeriorina), an extracytoplasmic coccidium from the white bream Blicca bjoerkna. J. Protozool. 39: 484-494

Morrison, C. M. (1991). Further observations on the sporogony of Eimeria sardinae in the testis of the herring Clupea harengus L. Can. J. Zool. 69: 1017-1024

Morrison, C. M., Hawkins, W. E. (1984). Coccidians in the liver and testis of the herring Clupea harengus L. Can. J Zool. 62: 480-493.

Morrison, C. M., Leger, J. P., Morrison, C. A. (1993a). Light and electron microscopic study of the pathology and merogony of Goussia gadi (Apicomplexa: Coccidia) in the swimbladder wall of haddock Melanogrammus aeglefinus. Dis, aquat. Org. 17: 113-125

Morrison, C. M., Leger, J. P., Morrison, C. A. (1993b) Gametogenesis of Goussia gadi (Apicomplexa: Coccidla) in the swimbladder wall of haddock Melanogrammus aeglefinus. Dis. aquat. Org. 17: 127-135

Morrison, C. M., Poynton, S. L. (1989). A new species of Goussia (Apicomplexa, Coccidia) in the kidney tubules of the cod, Gadus morhua L. J. Fish Dis. 12: 533-560

Odense, P. H. Logan, V. H. (1976). Prevalence and morphology of Eimeria gadi (Fiebiger, 1913) in the haddock. J. Protozool. 23: 564-571

Overstreet, R. M. Hawkins, W. E., Fournie, J. W. (1984). The coccidian genus Calyptospora n. $\mathrm{g}$ and family Calyptosporidae n. fam. (Apicomplexa), with members infecting primarily fishes. J. Protozool. 3: 332-339 
Paperna, I., Landsberg, J. H. (1985). Ultrastructure of the oogony and sporogony of Goussia cichlidarum, Landsberg and Paperna, 1985, a coccidian parasite in the swimbladder of cıchlid fish. Protistologica 21: 349-359

Paterson, W. B., Desser, S. S. (1981). Uttrastructure of macrogametogenesis, macrogametes and young oocysts of Eimeria iroquoina Molnar and Fernando, 1974, in experimentally infected fathead minnows (Pimephales promelas, Cyprinidae). J. Parasitol. 67: 496-504

Ryley, J. F. (1973). Cytochemistry, physiology, and biochemistry. In: Hammond, D. M., Long, P. L. (eds.) The Coccidia.

Responsible Subject Editor: W. Körting, Hannover, Germany
University Park Press, Baltimore; Butterworths, London; p. $145-182$

Steinhagen, D. (1991). Ultrastructural observations on merogonic and gamogonic stages of Goussia carpelli (Apicomplexa, Coccidial in experimentally infected common carp Cyprinus carpio. Eur. J. Protistol. 27: $71-78$

Steinhagen, D., Lukes, J., Körting, W (1990). Ultrastructural observations on gamogonic stages of Goussia subeputhelialis (Apicomplexa, Coccidia) from common carp Cyprinus carpio. Dis. aquat. Org. 9: 31-36

Manuscript first received: March 12, 1993

Revised version accepted: July 5, 1993 